\title{
A maioridade da Acta Cirúrgica Brasileira: estratégia para o ISI
}

\author{
The adulthood of Acta Cirúrgica Brasileira: strategy for ISI
}

\author{
Luiz Francisco Poli de Figueiredo ${ }^{1}$, Lydia Masako Ferreira ${ }^{1}$, Edna Frasson de Souza Montero² ${ }^{2}$ Alberto Goldenberg ${ }^{3}$ \\ 1. Co-Editor Científico Acta Cirúrgica Brasileira. \\ 2. Editor Associado Acta Cirúrgica Brasileira. \\ 3. Editor Científico Acta Cirúrgica Brasileira.
}

A Acta Cirúrgica Brasileira, graças à visão, dedicação e organização do Prof. Saul Goldenberg, vem conquistando progressivamente seu espaço como veículo de divulgação do conhecimento de vanguarda na área cirúrgica. Inicialmente indexada no LILACS, a maior visibilidade foi atingida pela indexação e veiculação dos artigos completos pela SciELO. Neste ano, a regularidade e a qualidade dos artigos foi reconhecida e a Acta conquistou definitivamente a comunidade científica internacional pela indexação no Medline e PubMed.

Nossa meta agora é a de ser indexada pelo JCR, Journal of Citation Report.

São diversos quesitos que compõe a estratégia para atingirmos este ambicioso objetivo.

- A língua inglesa deverá ser oficial. Portanto, todos os artigos deverão ser submetidos em inglês. Os artigos em português poderão ser considerados, desde que haja o compromisso de conversão para a língua inglesa caso o artigo seja aceito para publicação. É responsabilidade dos autores e quesito fundamental que o texto em inglês esteja impecável.

- Corpo editorial nacional e internacional. É exigência do JCR que o corpo editorial seja composto de formadores de opinião e por profissionais de comprovada inserção internacional, através de produção continuada reconhecida. A presença de revisores internacionais de reconhecido rigor científico é fundamental para embasar com solidez a solicitação de indexação pelo JCR, pois o testemunho destes quanto a qualidade e seriedade da revista é essencial.

- Alta qualidade dos artigos e das revisões. As revisões devem ser ágeis, rápidas e com rigor suficiente para a manutenção da mais alta qualidade dos manuscritos. A competitividade internacional é alta e a Acta somente será considerada pelo JCR se nossos artigos forem relevantes, bem selecionados e escritos de modo exemplar.

- Membros do corpo editorial como autores. Os membros do corpo editorial, tanto do Brasil quanto do exterior, devem publicar artigos originais relevantes, de competitividade internacional na Acta, acreditando no contínuo aprimoramento de nossa revista. Desta maneira, a citação dos artigos por outros autores ocorrerá de modo natural e por mérito.

Desta maneira, a nossa meta será atingirmos um fator de impacto progressivamente maior.

Prezados colegas, o desafio é muito grande porém nossa meta está baseada no historio de conquistas do Prof. Saul. O envolvimento, dedicação e contribuição de todos são decisivos para as próximas conquistas. A cirurgia brasileira merece! 